\title{
DELIMITANDO REGIONALIDADES EM $A$ ESCOLA DAS FACAS, DE JOÃO CABRAL DE MELO NETO
}

Bruno Brizotto*

RESUMO: Tomando como objeto de análise o livro de poemas $A$ escola das facas (1980), de João Cabral de Melo Neto (1920-1999), e tendo como referencial teórico afirmações de autores como Arendt (2012), Barcia (2004), Bourdieu (2003), Certeau (2002), Joachimsthaler (2009), Kaliman (1994), Pozenato (2003; 2009) e Santos (2009) podemos estabelecer o propósito deste ensaio: examina algumas regionalidades (ARENDT, 2012) presentes em poemas selecionados da referida obra de João Cabra (2008). As regionalidades analisadas estão localizadas espacialmente em uma região bem delimitada pelo eulírico: a região Nordeste do Brasil, particularmente o estado de Pernambuco. Alguns poemas, como "Cais pescador" e "Autocrítica", fazem um contraponto entre a região nordestina (Brasil) e a região da Andaluzia (Espanha). A análise também busca responder à seguinte questão: seria A escola das facas um texto regionalista?

PALAVRAS-CHAVE: Região; Regionalidades; $A$ escola das facas; João Cabral de Melo Neto.
* brunobrizotto@terra.com.br

Mestrando no Programa de Pós-Graduação em Letras

Cultura e Regionalidade da Universidade de Caxias do Sul.

ABSTRACT: Taking as object of analysis the book of poems The school of knives (1980), by João Cabral de Melo Neto (1920-1999), and having as theoretical reference statements of authors such as Arendt (2012), Barcia (2004), Bourdieu (2003), Certeau (2002), Joachimsthaler (2009), Kaliman (1994), Pozenato $(2003,2009)$ and Santos (2009), we can establish the purpose of this essay: examine some regionalities (ARENDT, 2012) present in selected poems of the referred work of João Cabral (2008). The regionalities analyzed are spatially located in a region well bounded by the I-lyrical: the Northeast region of Brazil, particularly the state of Pernambuco. Some poems, like "Pier fisherman" and "Self-criticism", make a counterpoint between the northeastern region (Brazil) and the region of Andalusia (Spain). The analysis also aims to answer the following question: would be The school of knives a regionalist text?

KEYWORDS: Region; Regionalities; The school of knives; João Cabral de Melo Neto. 
O poeta e diplomata brasileiro João Cabral de Melo Neto nasceu a 9 de janeiro de 1920, em Recife, capital do estado brasileiro de Pernambuco. Foi o segundo filho de Luiz Antônio Cabral de Melo e de Carmem Carneiro-Leão Cabral de Melo. Primo, pelo lado paterno do também poeta Manuel Bandeira e, pelo lado materno, do escritor Gilberto Freyre. A vivência, durante a infância (até completar dez anos), em engenhos de açúcar foi fundamental para poesia do autor. Ao longo de sua prolífica vida, João Cabral, além de poeta, dedicou-se à vida diplomática, desempenhando o cargo de embaixador do Brasil em diversos países, como, por exemplo, Reino Unido, França, Espanha, Portugal, Equador, Honduras, Senegal. Acerca das influências que o poeta recebeu para a sua escritura literária, podemos destacar: os poetas Charles Baudeleire, Paul Valéry, Stéphane Mallarmé, a poetisa Marianne Moore, os pintores Joan Miró, Piet Mondrian e Charles-Edouard Jeanneret-Gris, bem como a Literatura de Cordel brasileira. A estreia de João Cabral na literatura se dá em 1942, ano em que o poeta publica Pedra do sono, livro que "descreve um universo noturno, sombrio, mas com extrema plasticidade na elaboração das imagen de cunho surrealista." (SECCHIN, 2008, p. XXII). Além da obra inicial, podemos mencionar como representativas para a literatura nacional as seguintes: O engenheiro (1945), Psicologia da composição com a fábula de Anfion e Antiode (1947), O cão sem plumas (1950), O rio (1954), Quaderna (1960), A educação pela pedra (1966), Morte e vida Severina (1966), Museu de tudo (1975),
A escola das facas (1980), Auto do Frade (1984), Agrestes (1985), Primeiros poemas (1990), Sevilha andando (1990), Tecendo a manhã (1999). Sobre a forma de organizar os seus poemas, João Cabral declara: "Eu não gosto de publicar os poemas soltos: reúno-os e formo com eles um livro que corresponda a um conjunto formal.” (MELO NETO, 2008, p. XXXI). Percebe-se aí a importância que o poeta dava à formalização e à contenção da linguagem. Em 1968, João Cabral é eleito para a Academia Brasileira de Letras na vaga de Assis Chateaubriand (cadeira número 37). Toma posse no ano seguinte, no dia 6 de maio, sendo recebido por José Américo de Almeida. ${ }^{1}$ Em 1994, é publicada a Obra completa de João Cabral, organizada pela sua segunda esposa e poeta Marly de Oliveira. Em 1996, o Instituto Moreira Salles lança o primeiro número da série "Cadernos de Literatura Brasileira”, dedicando-o a João Cabral de Melo Neto. Em 2008, Antonio Carlos Secchin, tido pelo próprio João Cabral como um dos maiores intérpretes de sua obra, organiza uma segunda edição da Obra completa, apresentando como título João Cabral de Melo Neto: poesia completa e prosa Além de ter sido Membro da Academia Brasileira de Letras, fez parte da Academia Pernambucana de Letras e foi agraciado com diversos prêmios literários. Em 9 de outubro de 1999, falece, no Rio de Janeiro, aos 79 anos de idade.

Cronologicamente situando na Geração de 45, João Cabral de Melo Neto $^{2}$ é considerado pela crítica literária
1. O discurso de posse, bem como outras informações sobre o autor,
pode ser encontrado no site da pode ser encontrado no site da página: http://www.academia. org.br/ab//cgi/cgilua.exe/sys/start. htm? sid=337.

2. A inclusão (ou exclusão) de João Cabral na Geração de 45 é assunto polêmico na crítica literária brasileira. Como não é propósito de nossa investigação discutir essa questão, sugerimos a leitura de Santos (2012) e Melo Neto $(2008$, p. $719-732)$
EM TESE $\quad$ BELO HORIZONTE $\quad$ v. $19 \quad$ N. $3 \quad$ SET.-Dez. $2013 \quad$ BRIZOTTO. Delimitando regionalidades em A escola das facas [...] $\quad$ P. 109-125

\section{Crítica Literária, outras Artes e Mídias}


3. COUTINHO.A literatura no Brasil, p. 206.

4. BOSI. História concisa da literatura brasileira, p. 469

5. SECCHIN. Prefácio: João Cabral Do fonema ao livro, p. XIII.

6. CAMPEDELLI E ABDALA Jr. João Cabral de Melo Neto, p. 102.

7. Cf. INGARDEN. $A$ obra de arte literária.

8. Cf. ISER. $O$ ato da leitura: uma teoria do efeito estético, v. 2.

9. Em entrevista a José Geraldo Couto (Folha de São Paulo, Mais!, São Paulo, 22/05/1994), Joâo Cabral deixa bem clara essa questão de se um poeta áspero, dificil para o leitor: toce ve, por exemplo, que eu não tenho poemas cantantes, não tenho poemas de embalar. Eu procuro tropece, não uma linguagem em que ele deslize. O Pierre Reverdy dizi o poeta e um 'maçon' (pedreiro) Ele ajusta as pedras. O prosador e'cimentier, ele 'coule le ciment' (espalha o cimento). Eu procuro faz uma poesia que náo seja asfaltada, que seja uncalçánento de pedras, durma nem seja embalo." fragmento śa embalado." Esse (2003: 110).

0. MOISÉS. História da literatura brasileira, p. 419-420.

11. LUCAS. $O$ poeta e a mídia: Carlos Drummond de Andrade e João Cabral de Melo Neto, p. 93.

12. LUCAS. $O$ poeta e a mídia: Carlos Drummond de Andrade e João Cabral de Melo Neto, p. 93. brasileira como um dos maiores poetas de sua geração, o "mais influente"3 deles. Bosi anota que "da "nova objetividade', qualificação superior a 'neo-realismo', é alto padrão a poesia de João Cabral de Melo Neto.”4 Secchin, em arguta observação, assevera que "[...] autores como João Cabral, em vez de acrescentarem um capítulo [para a poesia brasileira], logram criar outra gramática." ${ }^{5}$ Nesse sentido, a poética cabralina exige um leitor crítico, conforme atestam as palavras de Campedelli e Abdala Jr.: "O rigor da construção dos poemas de João Cabral prevê lacunas interpretativas que deverão ser preenchidas pela criticidade do leitor." ${ }^{\prime}$ Mais do que o simples preenchimento ${ }^{7}$ ou a atualização ${ }^{8}$ das lacunas (ou espaços vazios) textuais, exige-se do leitor pensamento crítico acerca da realidade representada nos poemas, como é o caso de Morte e vida Severina, por exemplo. ${ }^{9}$ E Moisés sintetiza a criação literária de João Cabral de Melo Neto: “[...] tem um só rosto, de nítida coerência. Inalterável na temática e na dicção, embora variando o mote ou o jeito de glosá-lo."10 Para Lucas, a poética cabralina deve ser estudada sempre levando em consideração a não auto-referencialidade do poeta, pois interessa a João Cabral "o texto mais do que tudo." ${ }^{11} \mathrm{O}$ estudioso identifica, entretanto, um paradoxo na escritura literária do poeta: "Mas, paradoxalmente, o seu texto não pode desligar-se do chão, da história e das relações natais. É de um localismo obsessivo."12 Assim, João Cabral é, juntamente com Carlos Drummond de Andrade, um dos

maiores poetas que o cânone literário brasileiro apresenta em sua estrutura. Poucos poetas, hoje em dia, conseguem produzir poesia de excelente qualidade, como o fez o autor de A educação pela pedra.

No que concerne ao referencial teórico adotado para esta investigação, apresentaremos conceitos e ideias fundamentais, os quais servirão de base para o estudo das regionalidades presentes em A escola das facas.

O conceito de região, central para os estudos da regionalidade, não está restrito somente ao campo da Geografia, como lembra Pozenato: “[...] a região, sem deixar de ser em algum grau um espaço natural, com fronteiras naturais, é antes de tudo um espaço construído por decisão, seja política, seja da ordem das representações, entre as quais as de diferentes ciências." ${ }^{13}$ Mais do que uma realidade natural, a região é construída por um auctor, isto é, o indivíduo que determina como o espaço deve ser delimitado. Muitas vezes, essa determinação não respeita a realidade natural e muito menos a realidade social dos atores culturais, como é o caso do Neocolonialismo, processo de dominação política e econômica estabelecido pelos países europeus ao longo do século XIX e início do século XX sobre o continente africano e asiático. ${ }^{14}$ Nesse processo, "é possível falar de região histórica, região cultural, região econômica e assim por adiante, com fronteiras distintas no mesmo território físico." ${ }^{15}$ Dess
13. POZENATO. Algumas considerações sobre região $e$ regionalidade, p. 150.

14. Referimo-nos ao período 1876 1915. Segundo Hobsbawm (2011: 101), a "repartição do mundo entre um pequeno número de Estados [...] foi a expressão mais espetacular da crescente divisão do planeta em fortes e fracos, em 'avançados' e 'atrasados' [...]."

15. POZENATO. Algumas considerações sobre região e regionalidade, p. 150. 
16. BOURDIEU. O poder simbólico, p. 108.

\section{POZENATO. Algumas} considerações sobre região $e$ regionalidade, p. 152 forma, diferentes regiões coexistem, ainda que, às vezes, de forma nem sempre pacífica, em um mesmo território.

É possível perceber, então, que a ideia de região transcende as fronteiras da Geografia, sendo utilizada pela História, pela Linguística, pela Economia, pelos Estudos Culturais, pela Etnografia, pela Antropologia, e, é claro, também pelos Estudos Literários. Nesse sentido,

a região é o que está em jogo como objecto de lutas entre os cientistas, não só geógrafos é claro, que, por terem que ver com o espaço, aspiram ao monopólio da definição legítima, mas também historiadores, etnólogos e, sobretudo desde que existe uma política de "regionalização" e movimentos "regionalistas", economistas e sociólogos. ${ }^{16}$

Visto dessa forma, o espaço físico, foco da Geografia passa para um segundo plano no âmbito das outras disciplinas. Para os termos de nosso estudo, acolhemos a proposta de Pozenato acerca do conceito de região, visto não só em seu aspecto físico, mas como "uma rede de relações, em última instância, estabelecida por um auctor, seja ele um cientista, um governo, uma coletividade, uma instituição ou um líder separatista." ${ }^{17}$ Ou um poeta, um romancista, um contista, poderíamos acrescentar. Decorrente do fato de a região ser entendida como uma rede de relações, está o princípio da ausência de centro, basilar para o pensamento pós-estruturalista, como demonstram os estudos de Pierre Bourdieu, Michel Foucault, Julia Kristeva, Gilles Deleuze, Jacques Derrida. Este, por exemplo, em sua abordagem desconstrucionista, defende que não existe um centro de significado para um texto; este pode produzir um número infinito de significados. A Física Quântica também contribuiu para o questionamento da ideia de centro, na medida em que "no seu lugar surge a imagem (ou conceito?) de rede de relações pela qual transitam funções. Onde se verifica uma função, aí está o centro, pelo menos dessa função. Ou seja, não há centro." ${ }^{18}$ Assim, a rede de relações estabelecida pela região será completada por outras relações a serem feitas, sejam elas de proximidade ou de distância.

O estabelecimento de uma rede de relações em uma determinada região permite que ela se torne um "espaço criado por uma interação." ${ }^{19}$ Dessa forma, "num mesmo lugar, há tantas 'regiões' quantas interações ou encontros entre programas. E também que a determinação de um espaço é dual e operacional, portanto, numa problemática de enunciação, relativa a um processo 'interlocutório'." ${ }^{20}$ No caso de A escola das facas, percebe-se a interação entre o eu-lírico e a realidade ali representada, resultando num diálogo entre duas instâncias enunciativas. É no âmbito cultural que essa interação deve ser examinada, pois, dessa forma, o espaço será construído "por um conjunto de práticas, de ações e relações sociais." ${ }^{21}$
18. POZENATO. Algumas considerações sobre região $e$ regionalidade, p. 157.

19. CERTEAU. $A$ invenção do cotidiano, p. 212.

20. CERTEAU. $A$ invenção do cotidiano, p. 212.

21. SANTOS. Relatos de regionalidade: tessituras da cultura, p. 15.
EM TESE BELO HORIZONTE $\quad$ v. $19 \quad$ N. $3 \quad$ SET.-DE. $2013 \quad$ BRIZOTTO. Delimitando regionalidades em A escola das facas [...] $\quad$ P. 109-125

Crítica Literária, outras Artes e Mídias 
22. JOACHIMSTHALER. A literarização da região e a regionalização da literatura, p. 40-41.

23. KALIMAN. La palabra que produce regiones. El concepto de región desde la teoria literaria, $\mathrm{p}$. 14. No original. "La configuración subjetiva de la región en

cualquier individuo deriva de las negociaciones entre las imágenes que los discursos dominantes difundan y la información que el individuo ha recibido por $s$ experiencia personal."
A ideia de região também implica pensarmos no conceito de identidade, visto que um indivíduo, como o poeta João Cabral, via eu-lírico, se identifica com a região em que está localizado, ainda mais se esta região for a sua pátria. É nesse sentido que se voltam as atenções de Joachimsthaler, na medida em que articula os conceitos de região e identidade:

Uma região é, portanto, "simplesmente" uma condensação de espaço cultural (mais de uma pode se sobrepor em um só local) usada por indivíduos como motivo para a construção de identidades regionais, no que elas [as condensações] atribuem um sentido para a identificação de caráter identitário aos espaços. As identidades sobrepostas não se excluem umas as outras: elas são possíveis simultaneamente, mesmo com suas diferenças, pois, por princípio, as identidades regionais não seguem o principio de exclusão das identidades nacionais. ${ }^{22}$

A identificação que o sujeito (pensemos no eu-lírico de A escola das facas) tem com uma determinada região é estabelecida na relação dialética entre o exterior e o interior: "A configuração subjetiva da região em qualquer indivíduo deriva das negociações entre as imagens que os discursos dominantes difundem e a informação que o indivíduo recebeu por sua experiência pessoal." ${ }^{\text {23 }}$ Arendt, baseado em Mühler e Opp, também se posiciona em relação à ideia de identificação:
[...] a relação dos indivíduos com os bens culturais não é uniforme, já que inúmeros contatos culturais que se efetivam entre os grupos humanos resultam em diferentes identificações. E a identificação, segundo Mühler e Opp (2006, p. 18), significa tanto considerar-se pertencente a um grupo de pessoas, quanto conectar-se a um objeto por razões emocionais. A identidade do indivíduo resulta dessas identificações construídas no tempo e no espaço, na interação com diferentes pessoas e objetos. As identificações podem ser, em razão disso, temporárias, flutuantes e flexíveis, e não monolíticas, rígidas e eternas. ${ }^{24}$

O conceito de região enquanto rede de relações revela mais uma faceta: ele apresenta em sua estrutura "o caráter de regionalidade. ${ }^{25}$ Formulado por Pozenato em 1974, o conceito de regionalidade constitui marco teórico pioneiro no Brasil. De acordo com o autor,

a regionalidade está na representação de um universo regional, feita segundo um modo de ser regional. De uma maneira simplificada se poderá dizer que a regionalidade repousa sobre uma temática e um modus faciendi regionais, entendido este último não apenas como a utilização de uma técnica peculiar, mas como toda a maneira de se posicionar frente ao mundo, aquilo que se chama comumente 'estilo de vida', e que engloba tanto a práxis como o ethos que a preside. ${ }^{26}$
24. ARENDT. Do outro lado do muro: regionalidades e regiões culturais, p. 89.

25. POZENATO. Algumas considerações sobre região $e$ regionalidade, p. 151.

26. POZENATO. O regional e o universal na literatura gaúcha, p. 27.
EM TESE $\quad$ BELO HORIZONTE $\quad$ v. $19 \quad$ N. $3 \quad$ SET.-Dez. $2013 \quad$ BRIZOTTO. Delimitando regionalidades em A escola das facas [...] $\quad$ P. 109-125

Crítica Literária, outras Artes e Mídias 
27. Trata-se do clássico ensaio "Algumas considerações sobre região e regionalidade" integrante da coletânea de textos organizada por Feltes $\mathrm{e}$ Zilles, em homenagem a Jayme Paviani. $\mathrm{O}$ texto foi republicado por Pozenato em 2003, ocasião em que outros ensaios do autor foram trazidos a público.

28. POZENATO. Algumas considerações sobre região $e$ regionalidade, p. 151.

29. POZENATO. Algumas considerações sobre região e regionalidade, p. 151.

30. POZENATO. O regional e o universal na literatura gaúcha, p. 27.

31. POZENATO. O regional e o universal na literatura gaúcha, p. 27.

\section{POZENATO. O regional e o} universal na literatura gaúcha, p. 9.

33. É válido ressaltar que cada um desses autores apresenta um background teorico diferente. Mas fica evidente a influência de Pozenato sobre eles, seja direta ou indiretamente.
Retomando a discussão em $2001^{27}$, o autor estabelece uma distinção conceitual entre região, regionalismo, regionalização e regionalidade. Nesse novo contexto, Pozenato define a regionalidade nos seguintes termos: "A regionalidade pode ser definida como uma dimensão espacial de um determinado fenômeno tomada como objeto de observação."28 Mas que implicação isso pode ter? O autor a deixa bem clara: "Isto implica em admitir que o mesmo fenômeno, visto sob a perspectiva da regionalidade, pode ser visto sob outras perspectivas." ${ }^{29}$ Percebe-se, aqui, a influência das teses pós-estruturalistas sobre Pozenato.Transpondo para o nosso caso a questão da regionalidade, percebe-se que a forma utilizada por João Cabral para construir $A$ escola das facas revela a sua "maneira de se posicionar frente ao mundo" ${ }^{\text {, a }}$ ao escrever poesia em 1980, constituindo, assim, uma regionalidade, a sua regionalidade particular, ainda que não entendida apenas como "a utilização de uma técnica particular" ${ }^{1}$, como salienta Pozenato. Nesse sentido, são paradigmáticas as seguintes palavras do autor: "[...] a dimensão regional de uma obra [deve] ser examinada como elemento constituinte da obra, como regionalidade, e não como regionalismo." ${ }^{32}$ Aí estão algumas das raízes dos desenvolvimentos recentes do conceito de regionalidade, como proposto por Haesbert e Arendt. ${ }^{33}$

Na perspectiva de Haesbert, a regionalidade "estaria ligada, de forma genérica, à propriedade ou qualidade de 'ser' regional", que "envolveria a criação concomitante da 'realidade' e das representações regionais" ${ }^{34}$ Essas representações regionais não podem ser dissociadas, ou ainda, "que uma se coloque, a priori, sob o comando da outra - o imaginário e a construção simbólica moldando o vivido regional e a vivência e produção concretas da região, por sua vez, alimentando suas configurações simbólicas." ${ }^{35}$. Tomando essa definição de regionalidade, Arendt propõe uma conceituação mais abrangente, mais plural, que leva em conta as diferentes vicissitudes da realidade e da ficcionalidade:

penso que [existem], em sentido estrito, regionalidades, ou seja, múltiplas propriedades ou qualidades de ser regionais em uma única região. A ideia de regionalidade no singular dá a impressão de existir um bloco homogêneo, quando, na realidade, regionalidades díspares e conflitantes coabitam em um único espaço social, as quais levam a identificações divergentes. Há uma luta constante no campo das representações simbólicas, com a eliminação e a criação de novas fronteiras regionais, fruto das manifestações de autoafirmação das regionalidades. Dessa forma, existe um modo de ser regional não em forma de bloco compacto e coeso, mas cheio de fissuras e imperfeições. ${ }^{36}$

Dessa forma, uma obra de arte literária, por exemplo, apresenta várias e distintas regionalidades em sua estrutura textual. No momento em que examinarmos trechos dos poemas
34. HAESBAERT. Região, regionalização e regionalidade: questões contemporâneas, p. 8.

35. HAESBAERT. Região, regionalização e regionalidade: questões contemporâneas, p. 8.

\begin{tabular}{|c|c|c|c|c|c|}
\hline EM TESE & BELO HORIZONTE & v. 19 & N. 3 & SET.-DEZ. 2013 & BRIZOTTO. Delimitando regionalidades em A escola das facas [...] \\
\hline
\end{tabular}

\section{Crítica Literária, outras Artes e Mídias}


37. Ao lado das regionalidades internas estão as regionalidades externas, que se traduziriam por meio dos seguintes critérios: o levantamento da(s) editora(s) em que o autor publicou, o âmbito no qual as obras circularam e circulam (regional, suprarregional), a recepção, as condições de leitura, a publicidade literária, a participação em feiras do livro, concursos literários, eventos de lançamento de livros; enfim, uma investigação empírica em diferentes regiões culturais.

38. ARENDT. Do outro lado do muro: regionalidades e regiões culturais, p. 90.

39. BEZZI. Região: desafios e embates contemporâneos, p. 83.

40. OLIVEIRA. João Cabral de Melo Neto: Breve introdução a uma leitura de sua obra, p. LXXXVIII.

41. CAMPEDELLI E ABDALA Jr. João Cabral de Melo Neto, p. 91. de João Cabral surgirão as regionalidades internas, inerentes à análise do fato literário. ${ }^{37}$ São essas regionalidades, essas particularidades, essas especificidades, que fazem com que uma obra, uma região seja aquilo que ela é. "Regionalidades são, assim, especificidades que integram e constituem uma paisagem cultural" ${ }^{\prime 8}$, sintetiza Arendt. Enfim, região e regionalidade(s) são conceitos interligados, pois um necessita do outro para poder se constituir, efetivando, assim, um movimento dialético. São pertinentes, nesse sentido, as colocações de Bezzi: "[...] a região, hoje, deve ser vista pela perspectiva sistêmica, em que todos esses aspectos [aspecto físico, humano e econômico], interligados, conectados, possam constituir a realidade concreta que se materializa num determinado espaço que se denomina região." ${ }^{39}$

A obra de João Cabral que constitui o centro de nossa investigação é, como já mencionado, A escola das facas. A respeito do título do livro, ele seria, inicialmente, Poemas pernambucanos, "mas por sugestão de Antonio Candido tomou o de um dos poemas do livro." ${ }^{40}$ Sobre essa obra do poeta pernambucano, Campedelli e Abdala Jr. afirmam que se trata "de uma volta, com uma perspectiva lírico-crítica, para a situação pernambucana." ${ }^{41}$ De fato, é um retorno que o poeta realiza: se no princípio a sua poesia era bastante intelectual, é com $O$ cão sem plumas que a presença de Pernambuco começa a se tornar visível, atingindo o coroamento com Doi parlamentos e A escola das facas que, segundo o próprio autor, "são exclusivamente sobre Pernambuco. Eu sinto que a presença de Pernambuco pouco a pouco foi-se fazendo maior, cada vez está mais forte." ${ }^{42}$ Nessa direção, Secchin resume a proposta de A escola das facas:

Em $A$ escola das facas se abriga um inesperado veio memorialístico de João Cabral, até então marcado pelo pudor em incluir-se na cena do texto. Ressalte-se, todavia, que a enunciação em primeira pessoa e a convocação da herança familiar não implica, em absoluto, o abrandamento ou a cúmplice complacência do olhar do poeta. Nele o memorialismo serve, antes, para aguçar tensões e conflitos que o tempo não atenuou, e que muitas vezes serviram de estímulo à própria criação artística, a exemplo do que se lê em "Descoberta da literatura". ${ }^{43}$

O instrumento que "não implica, em absoluto, o abrandamento ou a cúmplice complacência do olhar do poeta" é expresso no próprio título do livro: a faca. Esta "é necessária como forma de defesa no conflito homem/terra"44, afirma Bertussi. Em poemas como "A escola das facas" e "As facas pernambucanas", a faca constitui-se como elemento fundamental para a demarcação das regionalidades, bem como para a representação da realidade ali exposta.
42. MELO NETO APUD GIOVANNI. Auto-retratos, p. 154.

43. SECCHIN. Prefácio: João Cabral Do fonema ao livro, p. XXV-XXVI.

44. BERTUSSI. João Cabral de Melo Neto: do regional ao universal, do Nordeste Brasileiro à Espanha, da miséria à vitalidade, p. 81 .
EM TESE $\quad$ BELO HORIZONTE $\quad$ v. $19 \quad$ N. $3 \quad$ SET.-Dez. $2013 \quad$ BRIZOTTO. Delimitando regionalidades em A escola das facas [...] $\quad$ P. 109-125

Critica Literária, outras Artes e Mídias 
45. MELO NETO. João Cabral de Melo Neto: poesia e prosa, p. 390.
Dos quarenta e cinco poemas que constituem A escola das facas, oito foram selecionados para o presente estudo da poesia de João Cabral de Melo Neto. São eles: "O que se diz ao editor a propósito de poemas", “A voz do canavial”, "A pedra do reino", “A voz do coqueiral”, “A escola das facas”, "As frutas de Pernambuco", "As facas pernambucanas" e "Autocrítica”. No decorrer de nossa análise, ficará evidente a região que é configurada nos poemas selecionados.

A epígrafe, proveniente do poeta e dramaturgo irlandês William Butler Yeats (1865-1939), que abre A escola das facas é altamente significativa, pois situa o leitor no espaço poético descrito pelo poeta: "rooted in one dear, perpetual place" que pode ser traduzida como "enraizados em um querido, eterno lugar". Esse "querido" e "eterno lugar" é Pernambuco, conforme a leitura dos poemas que sucedem a epígrafe sugere. Além disso, o autor dedica o livro "A meus irmãos", numa possível referência aos seus irmãos pernambucanos (podendo ser incluídos aqui o seu irmão de sangue Evaldo Cabral de Melo e os primos Manuel Bandeira e Gilberto Freyre), conterrâneos seus, que têm em comum o fato de terem como pátria o estado brasileiro de Pernambuco. Nesse sentido, são válidas as palavras de Joachimsthaler sobre região e pátria:

[...] "região", "pátria", torna-se espaço cultural para os nela nascidos ou para os que a ela se dirigiram, por meio da cons- ciência de sua particularidade, por meio do desenvolvimento do acúmulo cultural casual num sistema de (auto-)criação num 'espaço significativo,' num modo de expressão - tratado e elaborado de forma linguística, artística e/ou jurídica - de uma existência situada espacialmente. ${ }^{46}$

A formalização e a contenção da linguagem, marcas caracterizadoras da poética cabralina, corporificadas num conjunto formal, isto é, num livro, estão presentes em "O que se diz ao editor a propósito de poemas" ${ }^{\prime \prime 7}$ :

Eis mais um livro (fio que o último)

de um incurável pernambucano;

se programam ainda publicá-lo,

digam-me, que com pouco o embalsamo.

E preciso logo embalsamá-lo: enquanto ele me conviva, vivo,

está sujeito a cortes, enxertos:

terminará amputado do fígado,

terminará ganhando outro pâncreas;

e se o pulmão não pode outro estilo

(esta dicção de tosse e gagueira),

me esgota, vivo em mim, livro-umbigo.
46. JOACHIMSTHALER. A literarização da região e a egionalização da literatura, p. 30-31.

47. Percebe-se a influência de Arthur Rimbaud no título desse poema de João Cabral. O poeta pernambucano intitula seu poema "O que se diz ao editor a propósito de poemas"; já, Rimbaud intitula um de seus poemas "O que se diz ao poeta a propósito de flores".

EM TESE

BELO HORIZONTE

v. 19

N. 3

SET.-DEZ. 2013

BRIZOTTO. Delimitando regionalidades em A escola das facas [...] P. 109-125

\section{Crítica Literária, outras Artes e Mídias}


48. MELO NETO. João Cabral de Melo Neto: poesia e prosa, p. 391.

49. MELO NETO. João Cabral de Melo Neto: poesia e prosa, p. 391
Poema nenhum se autonomiza no primeiro ditar-se, esboçado, nem no construí-lo, nem no passar-se

a limpo do datilografá-lo.

Um poema é o que há de mais instável: ele se multiplica e divide,

se pratica as quatro operações

enquanto em nós e de nós existe.

Um poema é sempre, como um câncer? que química, cobalto, indivíduo

parou os pés desse potro solto?

Só o mumificá-lo, pô-lo em livro. ${ }^{48}$

Está manifesto por esse poema o desejo do poeta em não deixar seus poemas soltos, sem a presença de um elemento que os una: o livro. Sem ele, a criação poética perde o seu sentido, visto o poema ser "instável", um "câncer", um "potro solto". No momento em que o poema fizer parte de um livro ele estará estável, situado, relacionado com outros poemas, formando, assim, um conjunto. Se permanecer solto, "está sujeito a cortes, enxertos: / terminará amputado do fígado, / terminará ganhando outro pâncreas; [...]."49 Percebe-se, assim, que essa modalidade de "mumificar" o poema, "pô-lo em livro" constitui uma regionalidade, um traço distintivo do fazer literário de João Cabral de Melo Neto. O exame do quarto quarteto, na opinião de Azevedo, revela um João Cabral que busca "a mesma postura irônica [de Rimbaud] quanto à pretensão da sociedade moderna ou do poeta de domesticar a poesia. ${ }^{150} \mathrm{O}$ poeta pernambucano busca, desse modo, ainda que ironicamente, domesticar a poesia, como os três últimos quartetos dão a entender.

"A voz do canavial" identifica o local onde é desenvolvido o cultivo da cana-de-açúcar. Introduzida no Brasil no início do século XVI, a cana-de-açúcar foi a base da economia do nordeste brasileiro, na época dos engenhos. No poema em questão, o canavial apresenta a sua voz:

\section{Voz sem saliva da cigarra,}

do papel seco que se amassa,

de quando se dobra o jornal: assim canta o canavial,

ao vento que por suas folhas, de navalha a navalha, soa,

vento que o dia e a noite toda o folheia, e nele se esfola. ${ }^{5}$

A voz do canavial não é nada exuberante, límpida e acolhedora; ao invés disso, é "sem saliva", seca como o "papel
50. AZEVEDO. Idéias fixas, idéias movediças, p. 13.

51. MELO NETO. João Cabral de Melo Neto: poesia e prosa, p. 393.
EM TESE
BELO HORIZONTE
v. 19
N. 3
SET.-DEZ. 2013
BRIZOTTO. Delimitando regionalidades em A escola das facas [...]
P. $109-125$

\section{Crítica Literária, outras Artes e Midias}


52. Sobre este último aspecto, Cf. "Moenda de usina".

53. MELO NETO. João Cabral de Melo Neto: poesia e prosa, p. 394

54. MELO NETO. João Cabral de Melo Neto: poesia e prosa, p. 395.

55. MELO NETO. João Cabral de Melo Neto: poesia e prosa, p. 395. seco que se amassa" e dobrável como "quando se dobra o jornal”. Essa voz que "assim canta” representa o declínio dos engenhos, fundamental na era colonial brasileira, tendo como consequência a sua substituição pelas usinas. ${ }^{52}$ Outro fator que contribuiu para a decadência dos engenhos foi a mudança da economia brasileira para a monocultura do café. Assim, a voz do engenho não é mais viva como costumava ser no auge do cultivo da cana-de-açúcar. Elemento da natureza igualmente importante na demarcação dessa regionalidade nordestina (e brasileira) é o vento. Mesmo o vento não se sustenta perante a voz do canavial, pois ele, ao soar pelas folhas do canavial, "de navalha a navalha", folheando-o, "nele se esfola."

"A pedra do reino", pelo exame de seu título e pela dedicatória ("A Ariano Suassuna"), remete ao texto literário de Suassuna publicado em 1971, o Romance d'A Pedra do Reino e o Príncipe do Sangue do Vai-e-Volta. Nesse poema, o eu-lírico apresenta uma nova descrição do sertão: "Foi bem saber-se que o Sertão / não só fala a língua do não." ${ }^{53}$ E mais: é "o espaço mágico e o feérico, / sem o imediato e o famélico" ${ }^{34}$ formando um "fantástico espaço suassuna, / que ensina que o deserto funda." ${ }^{55}$ É um espaço fantástico, que pertence ao mundo das fadas (feérico). A referência ao poeta paraibano não se faz somente no título e na dedicatória, mas também no excerto "fantástico espaço suassuna”. Nota-se, assim, uma

EM TESE
BELO HORIZONTE v. 19
SET.-DEZ. 2013 nova forma de ver o sertão nordestino, constituindo uma regionalidade. Ainda que "Para o Brasil, ele [o sertão] é o Nordeste" ${ }^{56}$ e que "Para o litoral, o esqueleto é o ser, o estilo sertanejo" ${ }^{\text {" }}$, o eu-lírico faz questão de ressaltar que o indivíduo que vive no sertão apresenta as suas idiossincrasias, as suas qualidades ${ }^{58}$, como já vistas pela referência ao universo fantástico de Ariano Suassuna. Veja-se:

$$
3
$$

$\mathrm{Tu}$, que conviveste o Sertão

quando no sim esquece o não,

e sabes seu viver ambíguo,

vestido de sola e de mitos,

a quem só o vê retirante,

vazio do que nele é cante,

nos deste a ver que nele o homem não é só o capaz de sede e fome. ${ }^{59}$

O "viver ambíguo" do sertanejo constitui uma regionalidade, na medida em que a vida do sertanejo não é nada fácil, seja pelo clima que predomina no espaço geográfico que habita, seja pelas condições econômicas. Todavia, o que
56. MELO NETO. João Cabral de Melo Neto: poesia e prosa, p. 394.

57. MELO NETO. João Cabral de Melo Neto: poesia e prosa, p. 394.

58. O eu-lírico é enfático nesse ponto, afirmando: “Os escritores que do Brejo, / ou que da Mata têm o sestro / de só dar a vê-lo no pouco, no quando em que o vê, sertão-osso." (MELO NETO, 2008: 394). Fica claro por esses versos que esses escritores só apresentam o sertão e seu habitante, o sertanejo, de uma forma, a negativa, excluindo a possibilidade de mostrá-lo em seus aspectos positivos

59. MELO NETO. João Cabral de Melo Neto: poesia e prosa, p. 394-395.

\section{Crítica Literária, outras Artes e Mídias}


o eu-lírico enfatiza é o traço positivo do sertanejo: este não é só um "retirante" que não consegue sobreviver em seu meio; é um ser que "não é só o capaz de sede e fome." Ademais, esse "viver ambíguo" está "vestido de sola e de mitos", característica que reforça a ambiguidade da vida sertaneja: de um lado, a base sólida de seu ser, a sola (do sapato), que nada mais é do que o couro de boi curtido e preparado para manufaturar o calçado; de outro lado, o mito, aludindo a uma origem remota, mítica desse personagem nordestino. O sertanejo também é criador de um gênero literário popular escrito frequentemente na forma rimada, originado em relatos orais e depois impresso em folhetos: a literatura de cordel. Essa é uma regionalidade constitutiva da região Nordeste do Brasil, trazida pelos colonizadores portugueses, que instituíram Salvador como a primeira capital da colônia, ponto de convergência natural de todas as culturas, permanecendo assim até 1763, quando foi transferida para o Rio de Janeiro. O poeta Carlos Drummond de Andrade apresenta uma definição para a literatura de cordel, que nos ajuda a entender essa modalidade de expressão artística. Segundo Andrade,

a poesia de cordel é uma das manifestações mais puras do espírito inventivo, do senso de humor e da capacidade crítica do povo brasileiro, em suas camadas modestas do interior. $\mathrm{O}$ poeta cordelista exprime com felicidade aquilo que seus companheiros de vida e de classe econômica sentem realmente. A espontaneidade e graça dessas criações fazem com que o leitor urbano, mais sofisticado, lhes dedique interesse, despertando ainda a pesquisa e análise de eruditos universitários. É esta, pois, uma poesia de confraternização social que alcança uma grande área de sensibilidade. ${ }^{60}$

A literatura de cordel, juntamente com outras formas literárias (poesia, conto, romance), é uma das diversas possibilidades de os seres humanos conhecerem melhor o mundo que em vivem. ${ }^{61} \mathrm{O}$ que "A pedra do reino" apresenta como basilar é o fato de que "ao habitar uma região, é possível identificar-se positivamente com algumas regionalidades e, ao mesmo tempo, entrar em conflito com outras." ${ }^{2} \mathrm{O}$ eu-lírico se identifica com os traços positivos do sertão e do sertanejo, mas entra em conflito com a perspectiva (do Brasil) de que o Nordeste é sinônimo de seca, fome e retirantes. Regionalidades, na observação de Arendt, "implicam atitudes de resistência ou de participação, de hostilidade ou de aliança, de rejeição ou de aceitação, atuando ora como obstáculos e limites, ora como continuidades e elos de ligação."63

Ao contrário de "A voz do canavial", está a "A voz do coqueiral”. Enquanto aquela é seca, "sem saliva", "de navalha”, esta é a representação do amainamento da agressividade da lâmina, da faca. Veja-se:
60. ANDRADE APUD SLATER. $A$ Vida no Barbante: a literatura de cordel no Brasil, p. 2.

61. A temática da literatura de cordel também se faz presente em

62. ARENDT. Do outro lado do muro: regionalidades e regiões culturais, p. 96.

63. ARENDT. Do outro lado do muro: regionalidades e regiôes culturais p. 96.

EM TESE

BELO HORIZONTE

v. 19

N. 3

SET.-DEZ. 2013

BRIZOTTO. Delimitando regionalidades em A escola das facas [...]

P. $109-125$

\section{Crítica Literária, outras Artes e Mídias}


64. MELO NETO. João Cabral de Melo Neto: poesia e prosa, p. 402.

\section{O coqueiral tem o seu idioma:}

não o de lâmina, é voz redonda:

é em curvas sua reza longa,

decerto aprendida das ondas,

cujo sotaque é o da sua fala,

côncava, curva, abaulada;

dicção do mar com que convive

na vida alísia do Recife. ${ }^{64}$

A voz do coqueiral está em íntima relação com as ondas do mar e com os ventos alísios do Recife, graças a sua localização geográfica: os cocos, qualquer que seja a sua origem espalharam-se através dos trópicos, em particular ao longo da linha costeira tropical. Pelo fato de estarem localizados em zonas tropicais, os coqueirais têm essa relação viscera com o mar e o vento. Trata-se, nesse caso, de um coqueiral pernambucano, pois a "dicção do mar com que convive" está vinculada à "vida alísia do Recife." Nesse sentido, a voz do coqueiral revela as suas regionalidades constitutivas: (1) o coqueiral tem o seu próprio "idioma”, a sua voz "redonda”; (2) o coqueiral, pelo fato de estar em relação com as ondas do mar, aprendeu delas a "sua reza longa", que é expressa "em curvas";

(3) o aprendizado com as ondas, cujo sotaque incorporou, encontra-se na fala do coqueiral, que é "côncava, curva, abaulada”, ou seja, é uma fala em curvas, que vai ao encontro do movimento das ondas e do vento; enfim, é uma fala mansa acolhedora, na qual o eu-lírico se sente bem em ouvir.
O poema que dá título ao livro, "A escola das facas”, mostra que o alísio (vento regular) se transforma ao entrar em contato com os coqueirais e os canaviais. Dessa forma, essas duas plantas dão uma lição para o alísio: elas funcionam como a "escola das facas", em última instância. Veja-se:

O alísio ao chegar no Nordeste

baixa em coqueirais, canaviais;

cursando as folhas laminadas,

se afia em peixeiras, punhais.

Por isso, sobrevoada a Mata,

suas mãos, antes fêmeas, redondas,

ganham a fome e o dente da faca

com que sobrevoa outras zonas.

O coqueiro e a cana lhe ensinam,

sem pedra-mó, mas faca a faca,

como voar o Agreste e o Sertão:

mão cortante e desembainhada. ${ }^{65}$

Note-se que a lição dada pelo coqueiral e o canavial revela, desse modo, as regionalidades do alísio: antes de chegar ao Nordeste, ele apresenta uma essência "fêmea" e "redonda"; ao chegar ao Nordeste, essa mesma essência se modifica, pois, ao cursar "as folhas laminadas", ele se "afia em peixeiras, punhais", ganha "a fome e o dente da faca", e "sem pedra-mó, mas faca a faca" voa "o Agreste e o Sertão" com "mão cortante e desembainhada." O vento, antes manso e sereno, agora é
65. MELO NETO. João Cabral de Melo Neto: poesia e prosa, p. 403.
EM TESE
BELO HORIZONTE
v. 19
N. 3
SET.-DEZ. 2013
BRIZ0TTO. Delimitando regionalidades em A escola das facas [...]
P. $109-125$

\section{Crítica Literária, outras Artes e Midias}


66. BERTUSSI. João Cabral de Melo Neto: do regional ao universal, do Nordeste brasileiro à Espanha, da miséria à vitalidade, p. 82.

67. MELO NETO. João Cabral de Melo Neto: poesia e prosa, p. 406. uma mão cortante. Ele é mais incisivo que a própria faca. $\mathrm{Na}$ esteira dessa questão, Bertussi afirma que "o universo vivido se transforma em ameaça, tanto que não é mais a faca, mas a mão que precisa ser 'cortante e desembainhada." 66

Destoando dessa paisagem cortante, está o cenário erótico descrito em "As frutas de Pernambuco":

Pernambuco, tão masculino,

que agrediu tudo, de menino,

é capaz das frutas mais fêmeas

e da femeeza mais sedenta.

São ninfomaníacas, quase,

no dissolver-se, no entregar-se,

sem nada guardar-se, de puta.

Mesmo nas ácidas, o açúcar,

é tão carnal, grosso, de corpo,

de corpo para o corpo, o coito,

que mais na cama que na mesa

seria cômodo querê-las. ${ }^{67}$

Ainda que a masculinidade de um Pernambuco "que agrediu tudo, de menino" esteja presente, esse estado brasileiro também "é capaz das frutas mais fêmeas / e da femeeza mais sedenta”. Temos, assim, um jogo de opostos: masculinidade versus feminilidade. Os traços que constituem essa feminilidade revelam as regionalidades que a constituem: (1) a feminilidade é marca distintiva da mulher pernambucana, dada a sua "feemeza mais sedenta"; (2) o erotismo é explícito, pois elas são "ninfomaníacas, quase, / no dissolver-se, no entregar-se, / sem nada guardar-se, de puta."; (3) mesmo a acidez, característica de algumas, não é empecilho para que a sua doçura transpareça: "Mesmo nas ácidas, o açúcar, / é tão carnal, grosso, de corpo”; (4) o eu-lírico, observando o corpo dessas "frutas" pernambucanas, deixa claro o local onde "seria mais cômodo querê-las": "de corpo para o corpo, o coito, / que mais na cama que na mesa”. Essa última regionalidade poderia implicar que todas as mulheres pernambucanas são fáceis, dada a predisposição do eu-lírico em querê-las na cama. Porém, o verbo "seria" é uma marca do futuro do pretérito, que expressa hipótese e incerteza. Além de mostrar o traço erótico, o perfil dessas "frutas" evidencia a natureza feminil básica de tais personagens.

"As facas pernambucanas" constitui outro exemplo de como a faca é uma constante na realidade pernambucana e nordestina. Como consequência dessa imagem, podemos elencar algumas regionalidades: (1) o eu-lírico apresenta a imagem que "o Brasil, qualquer Brasil" tem "quando fala do Nordeste": "fala da peixeira, chave / de sua sede e de sua febre." ${ }^{68}$ Além de ser faca para cortar o peixe, a peixeira é uma faca muito comprida e afiada, que serve de arma. Veja-se:
68. MELO NETO. João Cabral de Melo Neto: poesia e prosa, p. 410.
EM TESE BELO HORIZONTE $\quad$ v. $19 \quad$ N. $3 \quad$ SET.-Dez. $2013 \quad$ BRIZOTTO. Delimitando regionalidades em A escola das facas [...] $\quad$ P. 109-125

\section{Crítica Literária, outras Artes e Mídias}


69. MELO NETO. João Cabral de Melo Neto: poesia e prosa, p. 410-411.

70. MELO NETO. João Cabral de Melo Neto: poesia e prosa, p. 410.
No Agreste e Sertão, a faca

não é a peixeira: lá,

se ignora até a carne peixe,

doce e sensual de cortar.

Não dá peixes que a peixeira

docemente corte em postas:

cavalas, perna-de-moça,

carapebas, serras, ciobas.

\section{Lá no Agreste e no Sertão}

é outra a faca que se usa:

é menos que de cortar,

é uma faca que perfura. ${ }^{69}$

(2) o eu-lírico também deixa claro que o Nordeste não é feito somente de praias, ou, ainda, que o seu litoral é da peixeira (na acepção de cortar peixe). Pelo contrário, "também é o Sertão, o Agreste / sem rios, sem peixes, pesca."70 Ao contrário da Zona da Mata, que é a zona mais urbanizada, industrializada e economicamente desenvolvida da região Nordeste, as sub-regiões do Sertão e do Agreste são as áreas mais sujeitas a extensos períodos de seca, com maior ênfase no Sertão; (3) é nesse espaço, pois, que a peixeira, enquanto arma, se estabelecerá como elemento central para a sobrevivência de alguns de seus habitantes. Observem-se os seguintes versos:
Esse punhal do Pajeú,

faca-de-ponta só ponta,

nada possui de peixeira:

ela é esguia e lacônica.

Se a peixeira corta e conta,

o punhal do Pajeú, reto,

quase mais bala que faca,

fala em objeto direto. ${ }^{71}$

(4) a utilização da faca no Sertão é muito diferente daquela feita no cais, no litoral: "O couro, a carne-de-sol, / não falam língua de cais"72 (MELO NETO, 2008, p. 411). A peixeira precisa se adaptar à realidade do sertanejo, ainda mais para a utilização do método de conservar alimentos de origem animal, a carne-de-sol. O trabalho com o couro também demanda uma utilização mais incisiva da faca, diferentemente dos cortes que são feitos nos peixes: "a sola em couro é capaz" de "cegar qualquer peixeira" ${ }^{\prime 3}$.

"Autocrítica" é um exemplo de poema que estabelece contraponto entre a região nordestina (Brasil) e a região da Andaluzia (Espanha). Veja-se:
71. MELO NETO. João Cabral de Melo Neto: poesia e prosa, p. 411.

72. MELO NETO. João Cabral de Melo Neto: poesia e prosa, p. 411.

73. MELO NETO. João Cabral de Melo Neto: poesia e prosa, p. 411.

EM TESE

BELO HORIZONTE

v. 19

N. 3

SET.-DEZ. 2013

BRIZ0TTO. Delimitando regionalidades em A escola das facas [...]

P. $109-125$

\section{Crítica Literária, outras Artes e Midias}


74. MELO NETO. João Cabral de Melo Neto: poesia e prosa, p. 430

75. GIMÉNEZ APUD BERUMEN. La frontera en el centro. Ensayos de literatura, p. 53. No original: cuya existencia nunca puede presumirse a priori - , se da cuando por lo menos una parte significativa de los habitantes de una region ha logrado incorpora a su proprio sistema cultural los símbolos, valores y aspiracione profundas de su región."
Só duas coisas conseguiram

(des)feri-lo até a poesia

o Pernambuco de onde veio

e o aonde foi, a Andaluzia.

Um o vacinou do falar rico

e deu-lhe a outra, fêmea e viva,

desafio demente: em verso

dar a ver Sertão e Sevilha. ${ }^{74}$

Duas regiões, com suas respectivas regionalidades, tornaram possível ao eu-lírico escrever poesia: "o Pernambuco de onde veio / e o aonde foi, a Andaluzia." O convívio do eu-lírico nessas duas regiões manifesta as regionalidades que o compõem, as quais estão atreladas ao seu fazer poético: "Um [Pernambuco] o vacinou do falar rico / e deu-lhe outra [Andaluzia], fêmea e viva, / desafio demente: em verso / dar a ver Sertão e Sevilha." Seja no estado brasileiro de Pernambuco ou na região da Andaluzia, com a cidade de Sevilha em foco, o poeta João Cabral estabelece vínculos, os quais ajudam a ver a constituição de uma identidade regional. Esta, de acordo com Giménez, "cuja existência nunca pode ser assumida a priori - é dada quando pelo menos uma parte significativa dos habitantes de uma região conseguiu incorporar a seu próprio sistema cultural os símbolos, valores e aspirações profundas de sua região." ${ }^{75}$
"Autocrítica" é o poema que encerra $A$ escola das facas, obra que apresenta um veio memorialístico do poeta João Cabral, fato que pode causar estranhamento ao leitor habituado com a sua poesia depurada, formal, geométrica. $\mathrm{O}$ poema em questão, na opinião de Bertussi, também causa efeito de estranhamento no leitor: "A nenhum leitor ocorre ser possível acreditar na veracidade dessa terceira pessoa, expressa pelo emissor do poema: é um João Cabral poetizado, sujeito repetitivo, quem leva na bagagem essas fortes experiências das duas regiões." ${ }^{" 76}$ Essa é uma regionalidade fundamental presente em A escola das facas, pois oferece ao leitor a possibilidade de estabelecer "um feixe de relações" com outras tantas relações, "tanto de proximidade quanto de distância." ${ }^{77}$ Tomando esse derradeiro poema como um ponto da rede de relações, muitas outras relações poderão ser estabelecidas. Afinal, como o próprio João Cabral defende que seus poemas devem estar dentro de um livro, formando um conjunto, torna-se viável o estabelecimento das diversas relações, que podem ser feitas sem obstáculos.

Pela investigação realizada, podemos concluir que a poesia de João Cabral, representada aqui por A escola das facas, não é regionalista, visto que não é fruto de um programa limitador, apologético ou mitificador, características que servem para estruturar um discurso regionalista. Como toda e qualquer obra de arte literária de excelente nível estético,
76. BERTUSSI. João Cabral de Melo Neto: do regional ao universal, do Nordeste brasileiro à Espanha, da miséria à vitalidade, p. 84.

77. POZENATO. Algumas considerações sobre região regionalidade, p. 157.
EM TESE
BELO HORIZONTE
v. 19
N. 3
SET.-DEZ. 2013
BRIZOTTO. Delimitando regionalidades em A escola das facas [... ]
P. $109-125$

\section{Crítica Literária, outras Artes e Mídias}


78. BARCIA. Hacia un concepto de la literatura regional, p. 43. No original: La literatura regiona literatura porque toda obras regiona, nace en un tiempo, en un lugar, en una región."
A escola das facas constitui um caso do que Barcia chama de literatura regional: "A literatura regional é o nome verdadeiro da literatura, porque toda obra é regional, nasce em um tempo, em um lugar, em uma região." ${ }^{78} \mathrm{O}$ critério que justifica o não-regionalismo do poeta é a forma como a região é representada nos poemas, forma que permite o estudo das regionalidades presentes nos poemas de $A$ escola das facas. Regionalidades são, assim, elementos essenciais que compõem um determinado cenário regional, neste caso, a região nordeste do Brasil.

\section{REFERÊNCIAS}

ARENDT, João Claudio. Do outro lado do muro: regionalidades e regiões culturais. RUA [online], v. 2, n. 18, p. 82-98, 2012.

AZEVEDO, Carlito. Idéias fixas, idéias movediças. In: MELO NETO, João Cabral de. A escola das facas e Auto do frade. Rio de Janeiro: Objetiva, 2008, p. 9-21.

BARCIA, Pedro Luis. Hacia um concepto de la literatura regional. In: RIVERO, Gloria Videla; CASTELLINO, Marta Elena (Ed.). Literatura de las regiones argentinas. Mendoza: Universidad Nacional Del Cuyo, 2004, p. 25-45.

BERTUSSI, Lisana. João Cabral de Melo Neto: do regional ao universal, do Nordeste brasileiro à Espanha, da miséria à vitalidade. Antares: Letras e Humanidades, n. 1, p. 68-91, jan-jun/2009.
BERUMEN, Humberto Félix. La frontera en el centro. Ensayos de literatura. Mexicali, Baja California: Universidad Autónoma de Baja California, 2005

BEZZI, Meri Lourdes. Região: desafios e embates

contemporâneos. In: SEI - Superintendência de Estudos Econômicos e Sociais da Bahia. (Org.). Desigualdades

Regionais. Salvador: Bigraf, v. 1, 2004, p. 39-87.

BOSI, Alfredo. História concisa da literatura brasileira. São Paulo: Cultrix, 1994

BOURDIEU, Pierre. O poder simbólico. Trad.: Fernando Tomaz. 6. ed. Rio de Janeiro: Bertrand Brasil, 2003.

CAMPEDELLI, Samira Youssef; ABDALA JR, Benjamin. João Cabral de Melo Neto. São Paulo: Abril Educação, 1982.

CERTEAU, Michel de. A invenção do cotidiano: 1. Artes de fazer. Trad.: Ephraim Ferreira Alves. Petrópolis: Vozes, 2002

COUTINHO, Afrânio (Dir.). A literatura no Brasil. 7. ed. São Paulo: Global, 2004

FELTES, Heloísa Pedroso de Moraes; ZILLES, Urbano. Filosofia: diálogos de horizontes. Caxias do Sul: Educs; Porto Alegre:

Edipucrs, 2001

GIOVANNI, Ricciardi. Auto-retratos. São Paulo: Martins Fontes, 1991

HAESBAERT, Rogério. Região, regionalização e regionalidade: questões contemporâneas. Antares: Letras e Humanidades, n. 3 , p. 2-24, 2010.

\section{Crítica Literária, outras Artes e Mídias}


HOBSBAWM, Eric J. A era dos impérios, 1875-1914. Trad.: Sieni Maria Campos e Yolanda Steidel de Toledo. São Paulo: Paz e Terra, 2011.

INGARDEN, Roman. A obra de arte literária. Trad.: Albin E. Beau, Maria da Conceição Puga e João F. Barrento. Lisboa: Fundação Calouste Gulbenkian, 1973

ISER, Wolfgang. $\mathbf{O}$ ato da leitura: uma teoria do efeito estético. Trad.: Johannes Kretschmer. São Paulo: Ed. 34, 1999. v. 2.

JOACHIMSTHALER, Jürgen. A literarização da região e a regionalização da literatura. Antares: Letras e Humanidades, Caxias do Sul, n. 2, p. 27-60, jul-dez/2009.

KALIMAN, R. La palabra que produce regiones. El concepto de región desde la teoría literaria. Tucumán: Universidad Nacional de Tucumán, 1994.

LUCAS, Fábio. 0 poeta e a mídia: Carlos Drummond de Andrade e João Cabral de Melo Neto. São Paulo: Editora Senac, 2003.

MELO NETO, João Cabral de. João Cabral de Melo Neto: poesia e prosa. Organizado por Antonio Carlos Secchin. 2. ed. Rio de Janeiro: Nova Aguilar, 2008.

MOISÉS, Massaud. História da literatura brasileira. São Paulo: Cultrix, 1989. (Volume 5, Modernismo)

OLIVEIRA, Marly de. João Cabral de Melo Neto: Breve introdução a uma leitura de sua obra. In: MELO NETO, João Cabral de. João Cabral de Melo Neto: poesia e prosa. Organizado por Antonio Carlos Secchin. 2. ed. Rio de Janeiro: Nova Aguilar, 2008, p.

LXXIX-LXXXVIII.
POZENATO, José Clemente. Algumas considerações sobre região e regionalidade. In: Processos culturais: reflexões sobre a dinâmica cultural. Caxias do Sul: Educs, 2003, p. 149-157.

O regional e o universal na literatura gaúcha. Caxias do Sul: Educs, 2009.

SANTOS, Rafael José dos. Relatos de regionalidade: tessituras da cultura. Antares: Letras e Humanidades, n. 2, p. 2-26, juldez/2009

SANTOS, Wladimir Saldanha dos. A Geração de 45: "uma quimera de origem" - Lêdo Ivo, João Cabral de Melo Neto e o discurso geracional. Revista Inventário, $11^{\text {a }}$ edição, p. 1-14, juldez/2012.

SECCHIN, Antonio Carlos. Prefácio: João Cabral - Do fonema ao livro. In: MELO NETO, João Cabral de. João Cabral de Melo Neto: poesia e prosa. Organizado por Antonio Carlos Secchin. 2. ed. Rio de Janeiro: Nova Aguilar, 2008, p. XIII-XXI.

SLATER, Candace. A Vida no Barbante: a literatura de cordel no Brasil. Trad.: Octavio Alves Velho. Rio de Janeiro: Civilização Brasileira, 198

\section{Crítica Literária, outras Artes e Mídias}

